\title{
Resistance to Powdery Mildew in Barley Recombinant Lines Derived from Crosses between Hordeum vulgare and Hordeum bulbosum
}

\author{
J.H. Czembor ${ }^{1}$, A. Pietrusińska ${ }^{2 *}$, U. Piechota $^{3}$ and D. Mańkowski ${ }^{4}$ \\ ${ }^{1}$ Plant Breeding and Acclimatization Institute - National Research Institute, \\ Independent Laboratory of Applied Biology, Radzikow, 05-870 Blonie, Poland \\ ${ }^{2}$ Plant Breeding and Acclimatization Institute - National Research Institute, \\ National Centre for Plant Genetic Resources: Polish Genebank, Radzikow, 05-870 Blonie, Poland \\ ${ }^{3}$ Plant Breeding and Acclimatization Institute - National Research Institute, \\ Plant Breeding and Genetics Department, Radzikow, 05-870 Blonie, Poland \\ ${ }^{4}$ Plant Breeding and Acclimatization Institute - National Research Institute, \\ Laboratory of Seed Production and Plant Breeding Economics, Department of Seed Science and Technology, \\ Radzikow, 05-870 Blonie, Poland
}

(Received 15 November 2018; Accepted 7 March 2019;

Communicated by A. Mohan)

\begin{abstract}
Barley recombinant lines obtained from crosses and backcrosses of common barley (Hordeum vulgare L.) cultivars Emir and Golden Promise with bulbosus barley grass (H. bulbosum L.) were tested against differential set of 14 Blumeria graminis D.C. Golovin ex Speer f. sp. hordei - synamorph Erysiphe graminis DC. f. sp. hordei Em Marchall isolates, pathogenic fungus causing powdery mildew. Powdery mildew resistance was found in 22 from 24 lines tested. Presence of unknown genes was postulated in 13 lines. In six of these lines the unknown genes were postulated present besides Mla12 allele originated from $H$. vulgare parent (cv. Emir). The only line resistant to infection, from all isolates used, was 181P94/1/3/1/1/1-2. Four other lines could be considered highly resistant, because they were susceptible to only one powdery mildew isolate. The possibilities to use the hybrid lines with identified resistance to powdery mildew, especially line 181P94/1/3/1/1/1-2 in barley breeding programs were discussed.
\end{abstract}

Keywords: Barley, Hordeum bulbosum, powdery mildew, Mla12, resistance genes

\section{Introduction}

Barley (Hordeum vulgare L.) is the fourth most important cereal crop in the world, being principal crop in certain regions. Barley is grown in places where other cereals are not suitable for farming due to harsh environmental conditions such as high altitude, low rainfall (<300 mm annually), or soil salinity (Bothmer et al. 2003a; Fischbeck 2003; Shrivastava and Kumar 2015). It is often attacked by barley powdery mildew fungus (Blumeria graminis DC. Golovin ex Speer f. sp. hordei - synamorph Erysiphe graminis DC. f. sp. hordei Em Marchall). Loss of yield caused by powdery mildew can reach up to 
$30 \%$, with average of 5-10\% across all the regions (Ceccarelli et al. 1995; Gong et al. 2013; Tratwal and Bocianowski 2014). Besides powdery mildew damage is manifested as a lowering of grain quality, especially for malting purpose (Balkema-Boomstra and Masterbroek 1995).

Powdery mildew on barley is considered as one of the most clearly characterized system of host-pathogen genetic interactions. There are more than 100 mildew resistance alleles that have been identified in barley. Barley cultivars with effective genes for resistance to major pathogens have been an efficient means for controlling major diseases and preventing yield losses (Fischbeck 2003; Weibull et al. 2003; Burdon et al. 2014). Barley breeders commonly used in their breeding programmes such major resistance genes as: Mla6, Mla 7, Mla9, Mla12 and Mla13 belonging to the Mla locus, and the resistance genes Mlk, Mlg, MlLa, Mlh and Mlra. However, virtually all of these genes were gradually overcome by virulent races within 4-5 years, when cultivars containing them were used on a large acreage. Exceptions are cultivars with the Mlo-resistance, carried by the recessive allele $m l o$, and resistance depends on MlLa resistance gene, which are efficient for long period use. Nevertheless, barley breeders, geneticists and plant pathologists are constantly looking for new efficient sources of powdery mildew resistance, in order to combine them with those already used in modern cultivars and to increase the resistance durability (Bonman et al. 2005; Shtaya et al. 2006c).

Based on genetic studies, barley genepool can be divided into three parts (Bothmer et al. 2003b). Common barley (H. vulgare L.) and wild barley (Hordeum spontaneum L.) belong to the primary genepool. $H$. spontaneum was used in many breeding programmes to transfer new desirable traits, like disease resistance and tolerance to abiotic stress (Fischbeck 2003; Backes et al. 2003; Pickering and Johnston 2005). The only one species, which is bulbosus barley (Hordeum bulbosum L.), belongs to secondary genepool (Pickering et al. 2004; Bothmer et al. 2003b; Pickering and Johnston 2005; Wendler et al. 2014; Wendler et al. 2015). Bulbosus barley is a perennial and occurs, both as diploid and autotetraploid cytotypes, in the Mediterranean region, West Asia, Caucasus Mountains and part of Central Asia including: Iran, Afghanistan, Turkmenistan, Uzbekistan, and Kazakhstan. (Bothmer et al. 1995). In the tertiary genepool of barley there are 29 other Hordeum species. These species are diploid, tetraploid and hexaploid forms and they are found in North and South America, Europe, the Middle East, Central Asia and South Africa (Bothmer et al. 1995). In some breeding programmes attempts have been made to use these species in crosses with $H$. vulgare but with limited success, due to strong crossability barriers (Bothmer et al. 2003; Pickering and Johnston 2005). Some of these barriers can be solved overcome by careful selection of parental genotypes and the environment in which crosses are being carried out. Pickering and co-workers described $H$. vulgare $\times$ H. bulbosum hybrids and their backcrossing to H. vulgare (Pickering et al. 2000). Several recombinant lines showed improved resistance to major barley pathogens, including leaf rust (Pickering et al. 2000).

Bulbosus barley grass, in the breeding programmes, has been used mainly to obtain doubled haploids (Pickering and Johnston 2005). In several reports H. bulbosum was described as a species with very high level of resistance to barley pathogens with pow- 
dery mildew amongst them (Johnston et al. 2013; Johnston et al. 2015; Pickering et al. 2004; Pickering et al. 2006; Pickering and Johnston 2005; Shtaya et al. 2007; Walther et al. 2000). Despite of the mentioned observations, the number of reports on H. bulbosum genetic investigations and on successful transfer of resistance to major pathogens resistance from $H$. bulbosum to $H$. vulgare is very limited (Zhang et al. 2001; Pickering et al. 2004; Pickering and Johnston 2005). In these reports hybrid lines of H. bulbosum $\times$ $H$. vulgare expressed resistance to such diseases as leaf rust, stem rust, powdery mildew, scald, septoria speckled leaf blotch, BaYMV/BaMMV (Pickering et al. 2000, 2006; Walther et al. 2000; Shtaya et al. 2007).

The objective of this study was to investigate powdery mildew resistance in recombinant lines obtained from crosses of $H$. bulbosum with $H$. vulgare. Each of analyzed line was derived from different cross so had potential to carried variable introgressed elements and genes.

\section{Materials and Methods}

\section{Plant material}

Twenty-four recombinant lines obtained from single crosses and backcrosses of common barley cultivars Emir and Golden Promise, with accessions of $H$. bulbosum, were tested (Table S1*). Recombinant lines were obtained at New Zealand Institute for Crop and Food Research, New Zealand (Pickering et al. 2000). In addition, the parental cultivars Emir and Golden Promise, were tested. The cv. Pallas, 24 Pallas near-isogenic lines (Kølster et al. 1986) and eight other cultivars, each carrying various known powdery mildew resistance genes, were used to determine virulence spectra of B. graminis $\mathrm{f}$. sp. hordei isolates. Susceptible cv. Manchuria was used as a positive inoculation control (Table S3).

\section{Pathogen}

Fourteen different isolates of B. graminis f. sp. hordei were used (Table S3), originated from the collections in Risø National Laboratory, Roskilde, Denmark; Danish Institute for Plant and Soil Science, Lyngby, Denmark; Edigenossische Technische Hochschule ETH, Zurich, Switzerland and Plant Breeding and Acclimatization Institute - National Research Institute, Radzików, Poland. The isolates were chosen according to differences in virulence spectra that were observed on the Pallas isolines differential set (Kølster et al. 1986) (Table S3), provided from Royal Agricultural and Veterinary University, Copenhagen, Denmark. Pathogen isolates were purified by single pustule isolation and were maintained and propagated on young seedlings of the powdery mildew susceptible cultivar Manchuria (CI 2330). Frequent virulence checks were made to assure the purity of isolates throughout the experiment.

*Further details about the Electronic Supplementary Material (ESM) can be found at the end of the article. 


\section{Resistance tests}

Five to 10 plants from each recombinant line were tested with 14 isolates of powdery mildew. Testing was conducted in the greenhouse. Plants were grown with at $16 \mathrm{~h}$ of light photoperiod and the temperature range of $16-22{ }^{\circ} \mathrm{C}$. Inoculation was carried out when plants were 10-12 days old (2 leaf stage) by shaking or brushing conidia from diseased plants. After 8-10 days of incubation, the infection types were scored with use of 0-4 scale, developed by Mains and Dietz (1930) (Table S4), where 0(4) score indicates Mloresistance. Plants scored 0-2 were included into the resistant group and plants scored 3 and 4 were included into the susceptible group.

\section{Postulation of resistance alleles}

Hypothesis about presence of the specific resistance genes was done on the basis of the gene for gene hypothesis (Flor 1956). Comparison of the reaction spectra of the tested lines with those of differential Pallas isolines after inoculation of differentiatial set of 14 $B$. graminis f. sp. hordei isolates was conducted. Identification of resistance genes was made by eliminating resistance genes not present in tested lines. Next step was determining the postulated and possible resistance genes.

\section{Statistical analysis}

In order to describe the differences between the tested lines and B. graminis $\mathrm{f}$. sp hordei isolates, a two-way ANOVA main effects analysis was carried out together with the Tukey's multiple comparison procedure. Data on the reaction of the tested lines and cultivars to the isolates, before the analysis, were subjected to square root transformation $x^{\prime}=\sqrt{x+0.5}$ (Maccaferri et al. 2010). In order to assess better the differentiation of the tested lines in terms of the total response to individual isolates, a multivariable cluster analysis was done, using the Square Euclidean Distance and Ward's Agglomerative Clustering Method. Statistical calculations were performed with Statistica 13.1 program (Dell Inc. 2016).

\section{Results}

Powdery mildew resistance genes were found in 22 from 24 lines tested (Table S2). Among them, nine lines $(65 \mathrm{~F} 17 / 4 / 2,102 \mathrm{C} 2 / 14 / 3 / 1,102 \mathrm{C} 2 / 16 / 2,102 \mathrm{C} 2 / 70 / 1 / 3$, 102C2/97/1, 119Y4/4/5/10, 169P15/8, 181P138/2 and 181P156/3) revealed Mla12 resistance gene, the same as in the $H$. vulgare backcross parent cv. Emir. In other six lines (36L53/1/3-7/2/1, 177L6/2/9, 200A3, 216L1, 36L50/3/5/1 and 38P18/8/1/10) Mla12 gene together with unknown resistance genes were postulated to be present. Unknown resistance genes only, were postulated in 7 lines (177L20/6/2-8/1/1-14, 181P94/1/3/1/1/12, 200A16/5/3, 216U3, 219W4, 36L36/4/1/7-17 and 182Q20/10). 
The line 181P94/1/3/1/1/1-2 showed broad resistance spectrum. It was resistant to all isolates of Blumeria graminis f. sp. hordei used. This line expressed three different reactions for inoculation with specific isolates: 0,1 and 2. Four other lines (177L20/6/2-8/1/1$14,200 \mathrm{~A} 16 / 5 / 3,216 \mathrm{U} 3$ and $219 \mathrm{~W} 4)$ can be considered highly resistant to powdery mildew, because of their resistance to 13 powdery mildew isolates.

Plants of two resistant lines (200A3 and 65F17/4/2) showed heterogeneous reaction after inoculation with some of the powdery mildew isolates. Among 24 lines used in research, two lines (219W4 and 36L36/4/1/7-17) revealed susceptibility to all used isolates. Barley cultivars used as back crossing parents showed lack of powdery mildew resistance (cv. Golden Promise) or resistance determined by gene Mla12 (cv. Emir) (Table S2). The only line resistant to infection with all isolates used was 181P94/1/3/1/1/1-2. Plants of this resistant line expressed three different resistance reactions to inoculation with specific isolates: 0, 1 and 2. Four other lines (177L20/6/2-8/1/1-14, 200A16/5/3, 216U3 and 219W4) could be considered highly resistant to powdery mildew because they were susceptible after infection with just one powdery mildew isolate. Plants of two lines (200A3 and $65 \mathrm{~F} 17 / 4 / 2$ ) showed heterogeneous reaction after inoculation with some of powdery mildew isolates used. Barley cultivars used as back crossing parents showed lack of powdery mildew resistance (cultivar Golden Promise) or resistance determined by gene Mla12 (cultivar Emir) (Table S2).

The results of the statistical analysis confirmed the results of powdery mildew resistance. The analysis of variance, carried out for the reactions of the tested lines and varieties to the set of isolates, allowed to find significant differences in reactions of genotypes tested $(\mathrm{MS}=1.4810, \mathrm{MSE}=0.1054, \mathrm{~F}$-statistic $=14.052, \mathrm{p}<0.0001)$ as well as in the pathogenicity of isolates used in the studies $(\mathrm{MS}=6.304, \mathrm{MSE}=0.105$, F-statistic $=$ $59.818, \mathrm{p}<0.0001)$. In order to better characterize better the differences in the reactions of the tested lines and varieties to the set of isolates, homogeneous groups were determined, based on the Tukey's test (Fig. S1). The tested lines and varieties were divided into 4 homogeneous groups. The cv. Golden Promise and lines: 38U4 / 1/3/8/1, 38U20 / 3/4/5/1, 182Q20 / 1 and 36L36 / 4/1 / 7-17 of the affected by powdery mildew formed the largest group. However, the rates of infection for 200A16/5/3, 219W4, 177L20/6/2-8/1/114, 216U3, 181P94/1/3/1/1/1-2, 177L6/2/9, 200A3, 216L1, 36L53/1/3-7/2/1, $38 \mathrm{P} 18 / 8 / 1 / 10,36 \mathrm{~L} 50 / 3 / 5 / 1$ lines are relatively low. The 200A16/5/3 and 219W4 lines were characterized by significantly lower paralysis than Emir cultivar. The 200A16/5/3 and 219W4 lines were characterized by significantly lower infection than cv. Emir.

Three main groups of the tested objects were obtained, with use of cluster analysis of variation of multiple experimental reactions of tested varieties and lines, into individual isolates (Fig. S2).

The first group, along with the cv. Golden Promise, is a group of barley lines characterized by the strongest reaction to individual isolates. The second group with the cv. Emir is a group of barley lines characterized by a weak interaction, with reference to particular isolates separately. The third group of barley lines expressed the weakest reaction to the isolates. The analysis of variance indicated that the pathogenicity of tested isolates was 
characterized by quite large differences $(\mathrm{MS}=1.186, \mathrm{MSE}=0.206, \mathrm{~F}$-statistic $=5.744$, $\mathrm{p}<0.0001)$. The results presented in Table S5 confirm the division into three homogeneous groups.

\section{Discussion}

Wild crop relatives are a rich source of genetic diversity. It is a good source of resistance to biotic stress, including diseases (Pickering et al. 2000; Walther et al. 2000; Thomas 2003). Wild species are more heterogenic than crops because were not subjected to strong breeding selection. In contrast to crops, wild relatives were subjected to natural selection evolution at the pathogen pressure. This process maintains much more genetic differentiation in resistance loci, than popularly applied breeding procedures, where intense artificial selection leads to genetic erosion. Bulbosus grass $(H$. bulbosum L.) is a wild species that belongs to barley secondary gene pool, which means presence of interspecific reproductive isolation. Pickering (2000) described the technique that broke cross-breeding barriers between barley and the bulbosus grass and allows introducing new genes to barley cultivars. From this time bulbosus grass an approachable source of new traits and genes for breeders. H. bulbosum was disclosed as a donor of some resistance genes, for example for fungal diseases: Rynchosporium secalis (Pickering et al. 2006), rust (Walther et al. 2000). It is also a donor of $M l H b$, resistance gene to powdery mildew. Pickering and coworkers (1995) located $M l H b$ on 2I (Introgressed) chromosome after introgressing to $H$. vulgare. Disclosing novel genes is very promising because powdery mildew is highly mobile and much variable fungus (Limpert et al. 1999). Limited number of known and used genes of powdery mildew resistance generates the need to search for new effective donors of resistance. Especially the known genes, excluding partial resistance mlo recessive allele, are race-specific and code vertical resistance. Almost all of these genes were overcome by the appearance of new aggressive pathotypesof the pathogen.

In the presented study seedling resistance test was used in order to describe infection types, expressed by barley recombinant lines after inoculation with differentiated isolates of $B$. graminis f. sp. hordei. This kind of testing is sufficient for disease resistance screening and is used commonly in breeding programmes, to postulate the presence of genes in modern cultivars and to screen for new sources of effective resistance (Brooks et al. 2000; Shtaya et al. 2006b). However, this kind of tests are not very useful to identify and describe partial resistance. For description of this kind of resistance there is a need to conduct measurements of resistance characteristics, additional to the infection type. Furthermore, partial resistance is generally better expressed at the adult plant stage (Martinez et al. 2001; Shtaya et al. 2006a; Ochoa and Parlevliet 2007; Wang et al. 2010). Final determination of the number of resistance genes and the type of their action in tested hybrid lines, may be established with the use of crosses and backcrosses among appropriate genotypes (Derevnina et al. 2015).

Three of analyzed recombinant lines (200A3, 216U3, 219W4) were previously described by Shtaya and co-workers (2007). Their research revealed high resistance level to powdery mildew in these three lines. These lines exhibited mainly scores: 0,1 and 2 after 
infection, the same as in our study. In this work, postulation of resistance gene was expanded for resistance genes not-represented in Pallas isolines, like $\mathrm{Ml}(\mathrm{St} 1)$ and $\mathrm{Ml}(\mathrm{St} 2)$ carried by cv. Steffi or Ml(Bw) - Borwina, Ml(Kr) - Kredit and Ml(1192) - Jarek.

The durability of the powdery mildew resistance effects presented in barley cultivars may be increased by using many different strategies. These strategies are: combining partial (minor genes) and race-specific (major) resistance genes, multiline cultivars, using partial resistance, combining different race-specific resistance genes into one cultivar and deploying many cultivars with different resistance genes in space (e.g. cultivar mixtures) or time (winter versus spring barley) (Finckh et al. 2000; Brown and Hovmøller 2002; McDonald and Linde 2002; Boyd et al. 2013). Very important for durability of resistance to powdery mildew is the proper use of new sources of resistance to this pathogen (Brown and Hovmøller 2002; McDonald and Linde 2002). It is expected that the new genes described in this paper will find (proper) application in this process.

Wild barley $H$. bulbosum is an important genetic resource for resistance to biotic and abiotic stress. Many scientists state that genepool of cultivated varieties is limited and that breeders are restricted to crossing within the primary genepool, which consists of $H$. vulgare (in form of modern cultivars and landraces) and its closest diploid relative, $H$. spontaneum (Russell et al. 2000; Pickering and Johnston 2005). However, presented study confirms the opinion that secondary barley gene pool can be a source of very valuable characteristics for barley breeding. Broadening the genepool of cultivated barley varieties and description of new sources of resistance are important for many reasons. Future strategies for the control of barley pathogens will have to focus on more ecologically acceptable pest control methods. Criticism of chemicals usage (pesticides, fungicides, herbicides, and mineral fertilizers) in agriculture is increasing in developed countries societies. Breeding for resistance represents an ecologically safe method. In addition to ecological, there are also economic arguments (use of fuel, labor, and special machines) and the argument about fungicide resistance development in strains of powdery mildew, which are in favour of breeding for resistance compared to instead of chemical control (Walters et al. 2012, 2013; Wulff et al. 2011; Ney et al. 2013).

Hybrid lines with identified resistance to powdery mildew originated from H. bulbosum, especially the line 181P94/1/3/1/1/1-2 resistant to all isolates used, should be used in breeding programmes to provide cultivars with highly effective resistance to this disease. In addition, $H$. bulbosum is a valuable source of resistance genes not only to fungal diseases, like powdery mildew and leaf rust, but also to barley mosaic viruses (Walther et al. 2000; Ruge et al. 2000; Ruge-Wehling et al. 2006). Based on the available literature it can be concluded, that breeding importance of $H$. bulbosum is constantly increasing due to its usefulness in inducing haploid plants as well as an effective source of resistance to biotic and abiotic stress.

\section{References}

Backes, G., Madsen, L.H., Jaiser, H., Stougaard, J., Herz, M., Mohler, V., Jahoor, A. 2003. Localization of genes for resistance against Blumeria graminis f. sp. hordei and Puccinia graminis in a cross between a barley cultivar and a wild barley (Hordeum vulgare ssp. spontaneum) line. Theor. Appl. Genet. 106:353-362. 
Balkema-Boomstra, A.G., Masterbroek, H.D. 1995. Effect of powdery mildew (Erysiphe graminis f. sp. hordei) on photosynthesis and grain yield of partially resistant genotypes of spring barley (Hordeum vulgare L.). Plant Breeding 114:126-130.

Bonman, J.M., Bockelman, H.E., Jackson, L.F., Steffenson, B.J. 2005. Disease and insect resistance in cultivated barley accessions from the USDA National Small Grains Collection. Crop Sci. 45:1271-1280.

Bothmer, R., Jacobsen, N., Baden, C.B., Jørgensen, R.B., Linda-Laursen, I. 1995. An ecogeographical study of the genus Hordeum. International Plant Genetic Resources Institute book, $2^{\text {nd }}$ edition. Rome, Italy. pp. $1-129$.

Bothmer, R., Sato, K., Knüpffer, H., Hintum, T. 2003a. Barley diversity - an introduction, Diversity in Barley (Hordeum vulgare). In R. Bothmer, T. Hintum, H. Knüpffer, K. Sato (eds). Elsevier Science B.V. Amsterdam, The Netherlands. pp. 3-8.

Bothmer, R., Sato, K., Komatsuda, T., Yasuda, S., Fischbeck, G. 2003b. The domestication of cultivated barley. In: R. Bothmer, T. Hintum, H. Knüpffer, K. Sato (ed.). Diversity in Barley (Hordeum vulgare). Elsevier Science B.V. Amsterdam, The Netherlands. pp. 9-27.

Boyd, L.A., Ridout, C., O’Sullivan, D.M., Leach, J.E., Leung, H. 2013. Plant-pathogen interactions: disease resistance in modern agriculture. Trends Genet. 29:233-240.

Brooks, W.S., Griffey, C.A., Steffenson, B.J., Vivar, H.E. 2000. Genes governing resistance to Puccinia hordei in thirteen spring barley accessions. Phytopathology 90:1131-1136.

Brown, J.K., Hovmøller, M.S. 2002. Aerial dispersal of pathogens on the global and continental scales and its impact on plant disease. Science 297:537-541.

Burdon, J.J., Barrett, L.G., Rebetzke, G., Thrall, P.H. 2014. Guiding deployment of resistance in cereals using evolutionary principles. Evol. Appl. 7(6):609-624.

Ceccarelli, S., Grando, S., and van Leur, J.A.G. 1995. Barley landraces of the Fertile Crescent offer new breeding options for stress environments. Diversity 11:112-113.

Dell. M. L. 2016. Statistica (data analysis software system), version 13.1. software.dell.com.

Derevnina, L., Singh, D., Park, R.F. 2015. The genetic relationship between barley leaf rust resistance genes located on chromosome 2HS. Euphytica 203:211-220.

Finckh, M.R., Gacek, E.S., Goyeau, H., Lannou, C., Merz, U., Mundt, C.C., Munk, L., Nadziak, J., Newton, A.C., Vallavielle-Pope, C., Wolfe, M.S. 2000. Cereal variety and species mixtures in practice, with emphasis on disease resistance. Agronomie 20:813-837.

Fischbeck, G. 2003. Diversification through breeding. In: R. Bothmer,T. H. Hintum, H. Knüpffer, K. Sato (eds), Diversity in Barley (Hordeum vulgare). Elsevier Science B.V., Amsterdam, The Netherlands. pp. $29-52$.

Flor, H.H. 1956. The complementary genetic systems in flax and flax rust. Adv. Genet. 8:29-54.

Gong, X., Li, C., Zhang, G., Yan, G., Lance, R., Sun, D. 2013. Novel Genes from Wild Barley Hordeum spontaneum for Barley Improvement. Proceeding of $11^{\text {th }}$ International Barley Genetic Symposium. pp. 69-89.

http://en.community.dell.com/techcenter/information-management/statistica/

Johnston, P.A., Meiyalaghan, V., Forbes, M.E., Habekuß, A., Butler, R.C., Pickering, R. 2015. Marker assisted separation of resistance genes Rph 22 and $R y m 16 \mathrm{Hb}$ from an associated yield penalty in a barley: Hordeum bulbosum introgression line. Theor. Appl. Genet. 128(6):1137-1149.

Johnston, P.A. Niks, R.E., Meiyalaghan, V., Blanchet, E., Pickering, R. 2013. Rph22: mapping of a novel leaf rust resistance gene introgressed from the non-host Hordeum bulbosum L. into cultivated barley (Hordeum vulgare L.). Theor. Appl. Genet. 126(6):1613-1625.

Kølster, P., Munk, L., Stølen, O., Løhde, J. 1986. Near-isogenic barley lines with genes for resistance to powdery mildew. Crop Sci. 26:903-907.

Limpert, E., Godet, F., Müller, K. 1999. Dispersal of cereal mildews across Europe. Agr. Forest Meteorol. 97:293-308

Maccaferri, M., Sanguimneti, M.C., Mantovani, P., Demontis, A., Massi, A., Ammar, K., Kolmer, J.A., Czembor, J.H., Ezarti, S., Tuberosa, R. 2010. Association mapping of leaf rust response in durum wheat. Mol. Breeding 26:189-228.

Martinez, F., Niks, R.E., Rubiales, D. 2001. Partial resistance to leaf rust in a collection of ancient Spanish barleys. Hereditas 135:199-203. 
McDonald, B.A., Linde, C. 2002. The population genetics of plant pathogens and breeding strategies for durable resistance. Euphytica 124:63-180.

Ney, B., Bancal, M.O., Bancal, P., Bingham, I.J., Foulkes, J., Gouache, D., Paveley, N., Smith, J. 2013. Crop architecture and crop tolerance to fungal diseases and insect herbivory. Mechanisms to limit crop losses. Eur. J. Plant Pathol. 135:561-580.

Ochoa, J., Parlevliet, J.E. 2007. Effect of partial resistance to barley leaf rust, Puccinia hordei, on the yield of three barley cultivars. Euphytica 153(3):309-312.

Pickering, R. 2000. Do the wild relatives of cultivated barley have a place in barley improvement? In: Logue S. (ed.) Barley genetics VIII: Proceedings of the 8th International Barley Genetics Symposium, vol I, Department of Plant Science, Waite Campus, Adelaide University, Australia. pp. 223-230.

Pickering, R., Ruge-Wehling, B., Johnson, P.A., Schweizer, G., Ackermann, P., Wehling, P. 2006. The transfer of a gene conferring resistance to scald (Rynchosporium secalis) from Hordeum bulbosum into H. vulgare chromosome 4HS. Plant Breeding 125:576-579.

Pickering, R.A., Hill, A.M., Michel, M., Timmerman-Vaughan, G.M. 1995. The transfer of a powdery mildew resistance gene from Hordeum bulbosum L. to barley (H. vulgare L.) chromosome 2 (2I). Theor. Appl. Genet. 91:1288-1292.

Pickering, R.A., Hudakova, S., Houben, A., Jonston, P.A., Butler, R.C. 2004. Reduced metaphase I associations between the short arms of homologous chromosomes in a Hordeum vulgare L. $\times$ H. bulbosum diploid hybrid influences the frequency of recombinant progeny. Theor. Appl. Genet. 109:911-916.

Pickering, R.A., Johnston, P.A. 2005. Recent progress in barley improvement using wild species of Hordeum. Cytogenet. Genome Res. 109:344-349.

Pickering, R.A., Malyshev, S., Künzel, G., Johnston, P.A., Korzun, V., Menke, M., Schubert, I. 2000. Locating introgressions of Hordeum bulbosum chromatin within the H. vulgare genome. Theor. Appl. Genet. 100:2731.

Ruge, B.M., Michel, R., Pickering, G. Proeseler, Wehling, P. 2000. Gene introgressions from H. bulbosum into cultivated barley cause resistance to different pathogens. Plant \& Animal Genome VIII, San Diego, p. 228.

Ruge-Wehling, B., Linz, A., Habekuß, A., Wehling, P. 2006. Mapping of Rym16Hb, the second soil-borne virus-resistance gene introgressed from Hordeum bulbosum. Theor. Appl. Genet. 113:867-873.

Russell, J.R., Ellis, R.P., Thomas, W.T.B., Waugh, R., Provan, J., Booth, A., Fuller, J., Lawrence, P., Young, G., Powell, W. 2000. A retrospective analysis of spring barley germplasm development from 'foundation genotypes' to currently successful cultivars. Mol. Breeding 6:553-568.

Shrivastava, P., Kumar, R. 2015. Soil salinity: A serious environmental issue and plant growth promoting bacteria as one of the tools for its alleviation. Saudi J. Biol. Sci. 22(2):123-131.

Shtaya, M.J.Y., Sillero, J.C., Flath, K., Pickering, R., Rubiales, D. 2007. The resistance to leaf rust and powdery mildew of recombinant lines of barley (Hordeum vulgare L.) derived from H. vulgare $\times$ H. bulbosum crosses. Plant Breeding 126:259-267.

Shtaya, M.J.Y., Sillero, J.C., Rubiales, D. 2006a. Search of partial resistance against Puccinia hordei in barley landraces from the Fertile Crescent. Plant Breeding 125:343-346.

Shtaya, M.J.Y., Sillero, J.C., Rubiales, D. 2006b. Screening for resistance to leaf rust (Puccinia hordei) in collections of Spanish barleys. Breeding Sci. 56:173-177.

Shtaya, M.J.Y., Sillero, J.C., Rubiales, D. 2006c. Search for resistance against Blumeria graminis in barley landraces from Fertile Crescent. Barley Newsletter 49.

Thomas, W.T.B. 2003. Prospects for molecular breeding of barley. Ann. Appl. Biol. 142:1-12.

Tratwal, A., Bocianowski, J. 2014. Blumeria graminis f. sp. hordei virulence frequency and the powdery mildew incidence on spring barley in the Wielkopolska province. J. Plant Prot. Res. 54(1):28-35.

Walters, D.R., Ratsep, J., Havis, N.D. 2013. Controlling crop diseases using induced resistance: challenges for the future. J. Exp. Bot. 64:1263-1280.

Walters, D.R., Avrova, A., Bingham, I.J., Burnett, F.J., Fountaine, J., Havis, N.D., Hoad, S.P., Hughes, G., Looseley, M., Oxley, S.J.P., Renwick, A., Topp, C.F.E., Newton, A.C. 2012. Control of foliar diseases in barley: towards an integrated approach. Eur. J. Plant Pathol. 133:33-73. 
Walther, U., Rapke, H., Proeseler, G., Szigat, G. 2000. Hordeum bulbosum - a new source of disease resistance - transfer of resistance to leaf rust and mosaic viruses from $H$. bulbosum into winter barley. Plant Breeding 119:215-218.

Wang, L., Wang, Y., Wang, Z., Marcel, T.C., Niks, R.E., Qi, X. 2010. The phenotypic expression of QTLs for partial resistance to barley leaf rust during plant development. Theor. Appl. Genet. 121:857-864.

Weibull, J., Walther, U., Sato, K., Habekuß, A., Kopahnke, D., Proeseler, G. 2003. Diversity in resistance to biotic stresses. In: R. Bothmer, T.H. Hintum, H. Knüpffer, K. Sato (eds), Diversity in Barley (Hordeum vulgare). Elsevier Science B.V., Amsterdam, The Netherlands. pp. 143-178.

Wendler, N., Mascher, M., Himmelbach, A., Johnston, P., Pickering, P., Stein, N. 2015. Bulbosum to go: A toolbox to utilize Hordeum vulgare/bulbosum introgressions for breeding and beyond. Mol. Plant 8:15071519.

Wendler, N., Mascher, M., Nöh, C., Himmelbach, A., Scholz, U., Ruge-Wehling, B., Stein, N. 2014. Unlocking the secondary gene-pool of barley with next-generation sequencing. Plant Biotechnol. J. 12:1122-1131.

Wulff, B.B.H., Horvath, D.M., Ward, E.R. 2011. Improving immunity in crops: New tactics in an old game. Curr. Opin. Plant Biol. 14:468-476.

Zhang, L., Pickering, R.A., Murray, B.G. 2001. A Hordeum vulgare $\times$ H. bulbosum tetraploid hybrid provides useful agronomic introgression lines for breeders. New Zeal. J. Crop Hort. 29:239-246.

\section{Electronic Supplementary Material (ESM)}

Electronic Supplementary Material (ESM) associated with this article can be found at the website of CRC at http://www.akademiai.com/content/120427/

Electronic Supplementary Table S1. Recombinant $H$. vulgare $\times H$. bulbosum lines, their parentages and chromosome location of $H$. bulbosum introgression

Electronic Supplementary Table $S 2$. Reaction of $24 H$. vulgare $\times H$. bulbosum recombinant lines and parental cultivars to infection with 14 differential isolates of Blumeria graminis f. sp. hordei according to Mains' and Dietz's (1930) scale

Electronic Supplementary Table S3. Differential Pallas isolines and resistant cultivars, and their infection types for the differential set of B. graminis f. sp. Hordei, according to Mains' and Dietz's (1930) scale. The 0(4) score indicates Mlo-resistance

Electronic Supplementary Table S4. Description of infection types and codes used (Mains and Dietz, 1930)

Electronic Supplementary Table S5. The average reactions of recombinant $H$. vulgare $\times H$. bulbosum lines to particular B. graminis f. sp. hordei isolates with homogeneous groups

Electronic Supplementary Figure S1. The average reactions of the $H$. vulgare $\times H$. bulbosum recombinant lines and parental cultivars to a differential set of Blumeria graminis f. sp. hordei isolates, divided into homogeneous groups

Electronic Supplementary Figure S2. Dendrogram of cluster analysis of the H. vulgare $\times H$. bulbosum recombinant lines and parental cultivars resistance to B. graminis f. sp. hordei received. The Square Euclidean Distance and Ward's Agglomerative Clustering Method 